\title{
Challenges of nursing care in psychosocial rehabilitation: a study from the constructionist perspective
}

\author{
Desafios do cuidado de enfermagem na reabilitação psicossocial: um estudo sob a perspectiva construcionista
}

Desafíos de la atención de enfermería en la rehabilitación psicosocial: un estudio bajo la perspectiva construccionista

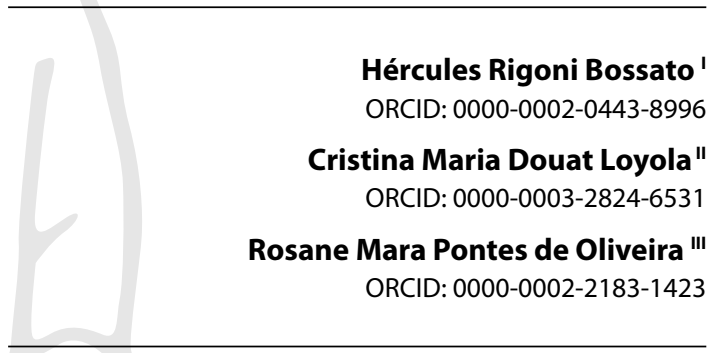

'Universidade Federal do Rio de Janeiro. Macaé, Rio de Janeiro, Brazil.

"Universidade Ceuma. São Luís, Maranhão, Brazil. I" Universidade Federal do Rio de Janeiro. Rio de Janeiro, Rio de Janeiro, Brazil

How to cite this article: Bossato HR, Loyola CMD, Oliveira RMP. Challenges of nursing care in psychosocial rehabilitation: a study from the constructionist perspective.

Rev Bras Enferm. 2021;74(Suppl 3):e20200408. doi:http://dx.doi.org/10.1590/0034-7167-2020-0408

\section{Corresponding author:}

Hércules Rigoni Bossato E-mail: profhercules@ufrj.br

EDITOR IN CHIEF: Antonio José de Almeida Filho ASSOCIATE EDITOR: Alexandre Balsanelli

Submission: $07-25-2020$

Approval: $10-20-2020$

\section{ABSTRACT}

Objective: To identify the nursing staff's difficulties in providing care in psychosocial rehabilitation to CAPS users. Methods: Qualitative study based on constructionism. Sixteen members of the CAPS nursing staff participated in the study in the city of Rio de Janeiro. The data collected in the interviews and observations were organized in Nvivo software and analyzed based on thematic content. Results: The difficulties identified were: the territorial violence that imposes a silence to the actions of CAPS, low user education as a barrier to protagonism, impaired family adhesion, the technical-conceptual discomfort of nursing in acting in the crisis and material and human of CAPS dismantlement. Final considerations: The challenges consist of overcoming staff exhaustion; however, they do not prevent nursing from betting on the possibility of protagonist care. Therefore, such care is dimensioned by the clinical-political-ethical relation in constant negotiation with the territory.

Descriptors: Psychiatric Nursing; Nursing Care; Rehabilitation; Mental Health; Mental Health Services.

\section{RESUMO}

Objetivo: Identificar as dificuldades da equipe de enfermagem na prestação do cuidado em reabilitação psicossocial aos usuários do CAPS. Métodos: Estudo qualitativo, baseado no referencial do construcionismo. Participaram do estudo 16 membros da equipe de enfermagem do CAPS na cidade do Rio de Janeiro. Os dados coletados nas entrevistas e na observação foram organizados no software Nvivo e analisados com base no conteúdo temático. Resultados: As dificuldades identificadas foram: a violência territorial que impõe um silenciamento às ações do CAPS, a baixa escolaridade do usuário como barreira ao protagonismo, a adesão familiar prejudicada, o desconforto técnico-conceitual da enfermagem em atuar na crise e o sucateamento material e humano do CAPS. Considerações finais: Os desafios consistem em superar o esgotamento da equipe, contudo não impedem que a enfermagem aposte na possibilidade do cuidado protagonizador. Para tanto, tal cuidado é dimensionado pela relação clínica-política-ética em uma negociação constante com o território.

Descritores: Enfermagem Psiquiátrica; Cuidados de Enfermagem; Reabilitação; Saúde Mental; Serviços de Saúde Mental.

\section{RESUMEN}

Objetivo: Identificar dificultades del equipo de enfermería en prestación del cuidado en rehabilitación psicosocial a los usuarios del CAPS. Métodos: Estudio cualitativo, basado en el construccionismo. Participaron 16 miembros del equipo de enfermería del CAPS en Rio de Janeiro. Los datos recogidos en las entrevistas y en la observación organizados en software Nvivo y analizados con base en el contenido temático. Resultados: Las dificultades identificadas son: la violencia territorial que impone un silenciamiento a las acciones del CAPS, baja escolaridad del usuario como barrera al protagonismo, adhesión familiar perjudicada, incomodidad técnico-conceptual de la enfermería en actuar en la crisis y desvalorización material y humana del CAPS. Consideraciones finales: Los desafíos consisten en superar el agotamiento del equipo, pero no impiden que la enfermería aposte en la posibilidad del cuidado esencial. Para tanto, tal cuidado es dimensionado por la relación clínica-políticaética en una negociación constante con el territorio.

Descriptores: Enfermería Psiquiátrica; Cuidados de Enfermería; Rehabilitación; Salud Mental; Servicios de Salud Mental. 


\section{INTRODUCTION}

Territorial and community-based service practices guide psychosocial rehabilitation. From this perspective, the goal is to break the asylum logic in health care.

Psychosocial Care Centers (CAPS) are services designed to receive users in psychological suffering, break with the logic of entertainment, stimulate social and family integration and support them in their efforts to seek autonomy, in addition to offering nursing, medical and psychological care. For this, it is necessary a transformative practice and the care guided on ethics beyond the institutionalizing practices ${ }^{(1)}$.

In this context, nursing has a fundamental role in establishing their daily care through mechanisms that allow the user to increase the territory's contractual power through the therapeutic relationship and the social support network ${ }^{(2-4)}$. In this way, nursing turns its actions towards increasing the autonomy and participation of the individual received in a mental health service ${ }^{(3)}$.

However, since the CAPS creation, it has been noted that the promotion of health and citizenship for the subject served in the service is still a significant challenge. This study raises the following question: What are the difficulties encountered by the nursing staff in the daily care of CAPS users?

The study is justified because the territorial-based service, linked to Primary Care in mental health assistance, still undergoes changes related to the challenges pointed out by the Brazilian Psychiatric Reform precepts. Mental health nursing also faces a past based on institutionalizing practices and the current need to integrate into a multidisciplinary group and carry out aid that produces autonomy, social inclusion, and psychosocial rehabilitation.

This research is relevant when listing the various challenges of the social, political, and clinical fields for the nursing staff's knowledge/practice in psychosocial rehabilitation.

\section{OBJECTIVE}

Identify the nursing staff's difficulties in providing psychosocial rehabilitation care to users of the Psychosocial Care Center.

\section{METHODS}

\section{Ethical Aspects}

As recommended by the National Health Council, the ethical aspects of research with human beings were complied with, following the Resolutions $n^{\circ} 466 / 2012$ and n ${ }^{\circ}$ 510/2016. The research project was submitted to Plataforma Brasil, being approved by the Research Ethics Committees of the Anna Nery School of Nursing /Hospital School São Francisco de Assis and the Municipal Health Secretariat of Rio de Janeiro.

\section{Theoretical-methodological reference}

It is a research from the perspective of Kenneth J. Gergen's social constructionism. It is an apologetic reference to a relational theory linked to practice. Therefore, it is referred to in theoretical descriptions that are often part of our daily experiences through the social construction of collectivized meanings ${ }^{(5)}$. Thus, employing the constructionist perspective implies thinking of the encounter and research as a possible space of transformation for innovative social construction in psychosocial rehabilitation. Thus, social constructionism is also a reference for nursing care studies in this scenario as nursing work must promote health in a non-exclusive way and associated with humanist principles.

\section{Type of study}

Qualitative descriptive-exploratory study. This research was conducted and structured based on the Equator Network's Standards for Reporting Qualitative Research (SRQR) instrument to guide the study methodology ${ }^{(6)}$.

\section{Methodological procedures}

The research used unstructured interviews and participant observation with the nursing staff who worked in psychosocial care assistance when an MP3 audio recorder registered the interviews and observations written in the researcher's field journal.

\section{Study scenario}

The research scenario took place in two type III Psychosocial Care Centers (CAPS), located in the city of Rio de Janeiro. One of the services is close to a favela, and the other is located in a more central and urbanized region. The research period was from September 2017 to January 2018.

The researchers are not part of the study scenarios' assistance team and have no professional relationship with the participants. It is important to emphasize that only one researcher was present at the data collection.

\section{Data source}

The selection of participants took place through the technique of convenience sampling and intentional choice. It was included nurses and technicians with a period equal to or greater than six months, with a permanent or temporary employment contract. The exclusion criterion was being on vacation during the study. Sixteen participants were interviewed, of whom nine (56\%) were nursing technicians and five (44\%) nurses. The average time of working in CAPS was three years.

\section{Data collection and organization}

Data production took over 112 hours of participant observation and unstructured interviews, and each statement lasted an average of one hour. The interviews and recording of the observations stopped after exhaustiveness of communication when noticed the repetition of themes.

Data from unstructured interviews and participant observation were handled manually and transcribed in a Microsoft Word 2016 program. These interviews were returned to the respective study participants via personal email to approve the 
transcribed content. It is worth mentioning that no participant requested changes to the material. Researchers used the letter "I" to identify interviewees' statements accompanied by a number corresponding to the response order.

For data organization and codification, the study used the NVivo 12 Pro software, which is a tool for thematic content analysis in qualitative health research that allows creating categories, coding, filtering, searching, and questioning data, in order to answer questions of a scientific study ${ }^{(7)}$.

\section{Data analysis}

Data coding in the NVivo software was performed in pairs. A content analysis was performed after organizing and encoding data, where those data from statements transcripts and observation records were analyzed. The study approaches, in the light of social constructionism, the following thematic categories for the production of meaning: 1) Territorial violence imposes a silence on the actions of the Psychosocial Care Center; 2) The low level of user's education as a barrier to protagonism; 3) Diminished family participation; 4) Technical-conceptual discomfort of nursing while acting in crisis; 5) The material and human wrecking of the Psychosocial Care Center.

\section{RESULTS}

\section{Territorial violence silencing the Psychosocial Care Center}

Territorial violence was a phenomenon that had the most significant expression of meanings. Such evidence is related to urban violence, drug trafficking, police violence, social inequalities, public security, and little investment in public policies in the territory:

From the drug trade [...] he couldn't get in this area because of drug debts, do you get it? And people respect he is in treatment, it's only respect, but if they have an opportunity, they won't let it pass by. (14)

This social vulnerability through territorial violence prevents CAPS from acting more widely:

[...] Today it is complicated, we're not moving around anymore, we're not developing more territorial actions with users because of the territorial violence; at any time of the day, at any moment, there's a confrontation, no scheduled time. This interferes with their access to the service, people's access to the community. (I1)

Violence in favelas and vulnerable territories imposes a heavy burden on the well-being of the population ${ }^{(8)}$ :

We end up exposing ourselves, now going up there in the community to catch a patient who is ill [...] in fact, the firemen or SAMU won't arrive in the majority of places up there also because of the territorial risk (I1)

[...] you are often approached by someone with a rifle getting to know if you are a health professional or a uniformed policeman who wants to enter the territory. (18)
Moreover, violence in health services is a phenomenon that has provided mental illness in the nursing staff ${ }^{(9)}$ :

[...] The drug trafficking personnel are almost always on the street, because they are usually armed, so we can't get up to the community, but we are very lucky that this CAPS works almost together with a family clinic, so the community health workers help us a lot. (17)

CAPS, too, is a place to escape from territorial violence:

Because many don't come, so we have to go to the patient's house to make them take this medication, and sometimes we can't cope with the demand for the service and the territorial violence. (I1)

I think they, in the territory, get very quiet, if they participate in some activity there is minimal and they really come in search of CAPS which is where they feel safer and feel better and have a voice. They have no voice there; they are just one more that are manipulated. (16)

According to data from the field journal, researchers have observed that violence related to police conflicts with drug trafficking has generated distress and fear among CAPS users and professionals. Data collection took place on a day of intense gunfire in the community close by, so researchers needed to stop data gathering and wait for the staff members' notice to return to work. It was noticed that some members of the nursing staff already accepted such an episode as a daily part of the routine.

The violence in CAPS III territory in the city of Rio de Janeiro brings an aggravating factor for the physical integrity of the individual suffering psychological distress and/or mental disorder and the user due to the difficulty of exercising his protagonism and citizenship. Social violence is configured as an aspect that further marginalizes the individual inserted in CAPS and hinders the territory's work and therapy.

\section{User's low education as a barrier to protagonism}

In CAPS, the difficulty of literacy generates obstacles of communication, instruction for rights, and understanding about therapy. Expressing oneself is not something easy for the user, and even if the nursing staff creates mechanisms to overcome this barrier, it continues to mark life in society:

[...] he doesn't accept the medication precisely because he doesn't have knowledge of that medication and, thus, the question of society, again speaking, it is difficult for us to integrate them, even because he can't read, you know? He isolates himself more. It gets harder to work like that. That's it, it's complicated, complicated when the user is illiterate. (I5)

For constructionism, communication is in the relationship in which the subjects produce meanings. Therefore, people speak from the perspective of a cultural tradition ${ }^{(5)}$ :

The nursing care in this protagonism [...] we have here a coffee shop with letters, for example, where people were stimulated to take out small passages or words and there, they formed... With that the person started to discover themselves. As I said, they came 
out of anonymity and saw that they were a person, they could do things in this sense. (12)

[...] I haven't seen here yet a literacy workshop that would be interesting, I'm not talking about creating a school, but it would be something like "Let's read a book, let's see how to read this book", start all over again, start with those books that you open like this. (113)

It is important to emphasize that there is an initiative for user access to literacy. It is important to emphasize that there is an initiative for user access to literacy. Such mechanism is related to creative communication through workshops and encouragement from the nursing staff:

We have many users who are semi-illiterate. Many, many, many, right? Because it's something very verbalized, because it's psychosocial attention, something very much of the conversation, it's something very [...] so, I guess it hasn't been too much of a problem. (I2)

We here at CAPS when we see that a patient is not literate, hasn't finished his/her studies, we see their desire to go back to school and enroll him/her, go after that, make them take the course. Here we have a free number of options as far as the patient wants to go, so much so that we even insert them in the workplace, when we have a job. (E16)

The researchers realized the need for a female user to be literate because she had asked the members of the Center in assembly to learn to read and write. In the reality of CAPS III, many subjects did not have the opportunity to become literate due to financial and social issues when they needed to work early or were unable to attend school. This deprivation of education access was more pronounced in patients who experienced long-term hospitalizations and institutionalization in psychiatric hospitals.

\section{Compromised family adherence}

It is clear the concern of the CAPS nursing staff with family participation:

There are many families who still see CAPS as if it were a madhouse [...] everybody gives trouble; the families are not aware that their relative does not need to be hospitalized to be cared for. (I11)

[...] the family is the big problem, even the fact that they stay, because sometimes they don't need to stay, and the family insists, the family makes no effort and threatens if you don't let them stay here and not take them in, they threaten to put them in a psychiatric hospital! (113)

The family is part of the partnership of care to the individual who suffers psychically but needs to receive the appropriate support to overcome situations of physical and emotional distress and should find, in the auxiliary mental health services, the treatment for their needs and support for their restructuring ${ }^{(10)}$ :

If the family has no awareness, they simply does not understand the issue of their relative disease [...] And this is exactly where they can find the right words so that they can understand and promote how they will ... to create alternatives to deal with it in everyday life. (16)

It makes all the work difficult; sometimes we are here, we liberate the individual well, he has become well and so. He's been there for a while, but we can send him home, because he is well organized, but the family doesn't want to receive the individual at home. (111)

The presence of psychic suffering among family members, possibly with a mental disorder, is a determining factor for non-adherence to treatment and the absence of co-responsibility:

[...] Sometimes the family also needs to be cared for and then they can't bring this person, this user. Sometimes, the network. (112)

There are family members that we really need to attend, receive individually, sometimes we even need to separate the reference, no matter the family is not treated, does not need a drug treatment, or does not have a disorder, but needs care. (I14)

In psychosocial care, user care proposals are not just a technical-professional issue since the subject's suffering involves his/her social environment, therefore, family. The family is a fundamental part of attending the protagonist's care, and their withdrawal from this therapeutic process harms the user's protagonism.

\section{Nursing distress while acting in crisis}

In the spaces of CAPS, intervention in crises is always a moment of great tension in the relations between the staff and the user, since this restraint has been predominantly physical and chemical, losing the community and institutional dimensions.

We talk about a substitute service to the asylums and that will deal with the crisis, which at first is very difficult to deal with. We always try to establish the bond. Then, after medication, without having a response, restraint [...]. So, sometimes it's hard to deal with. (I1)

We who stay at the end, because patient is agitated, call nursing. Nursing that is there, as they say in militarism, the infantry that is there in front. So nursing is the first to be called, so experience, I have several experiences both with physical restraint and chemical restraint (18)

Concerning the restraint in crises carried out in CAPS III, the nursing staff has an explicit feeling of discomfort:

Afterwards, it gives me a relief, but I feel sorry for the user. I already had an issue for not participating in the restraint, and when I got here, he was already restrained. After that he started crying, and I felt sorry for him. (I12)

It's complicated, several feelings like that... It's very bad [...] when a patient is aggressive. Nobody likes to see anybody restraint right? I don't like to see an animal locked up, imagine a person, you know? It's awful to talk about it. (I16)

Such discomfort is intrinsically linked to the difficulty of communication and understanding of the meanings during the madness crisis, which can involve unpleasant experiences for the nursing staff and, especially, for the user: 
Restraint is really what affect us a lot, it hurts us a lot. The bet in not trying to restrain, it's too high, we put ourselves in too much risk. I've taken punches, I've taken elbows, I've taken a chair in my back. I'm going to stay, to be careful, not hold back, let's try establishing a bond, but sometimes this is unbearable, because we try to do it differently. (I1)

I wouldn't like to be, I wouldn't like to be stuck there for several hours in physical restraint. It's bad, it's very bad, but there are moments that is necessary. Both for the user, for the patient, and for the professional. So there is no way, there is no way for us, we have to put the patient in a physical and even chemical restraint. (18)

The nursing staff feels uncomfortable and unprepared regarding the therapeutic meaning of physical restraint during crisis; also, there is no real participation of other CAPS professionals in this clinical management of urgency:

Generally, I don't like physical restraint, it takes me back to the past, it takes me back to violence, many acts that happened in the past, but there is a difference, when we need to do it. (I3)

It's not that it bothers me, but I think that the staff doesn't help us very much and we are very alone doing it; I understand that mechanical restraint is a working tool, but we have to be very gentle while doing it. (114)

The participants brought the need for this restraint, despite the unease inside the nursing staff:

It is something inhuman to reproduce this issue of punishment and try not to understand the subject when he tries to communicate through this construction with the psychotic base, to see that it is very invasive, unbearable for him. (I15)

The crisis is present in CAPS, and it is expected to happen within this space of care for critically ill patients. Despite the discomfort, the staff manages, even with difficulties facing the crisis's urgency, to humanize the intervention to return to autonomy and resocialization ${ }^{(11)}$.

\section{The wrecking of the Psychosocial Care Center}

The wrecking of CAPS is a reality evident by the lack of human and material resources. There seems to be no interest from the municipal administration in providing good planning:

I make many home visits. The difficulty is transportation, there is no transportation. I make it by own means with my own car. (I2)

We see which user has an escort to pay for the other's ticket. Sometimes we end up having to pay for one ticket or another. I think a lot of the financial, there are people who don't have any money, we pass the CAPS card or it's the end of the month and all the money has gone, and sometimes the user ends up not being able to go. (114)

The data from the field journals showed that, in an assembly of users on valorization of SUS and public and territorial services, the agenda focused on the discussion related to the demand for timely payments and more resources from the city to the
CAPS. There is tension in health professional participants' speech when they address the issue of work overload due to the lack of investments and human resources:

I am tired, stressed with my work. Last week I was with a continuous pain in the back of my head, I'm hypertensive, I am almost 40 years [...] It was the time for me to leave and come here, I had an akathisia, I panicked [...] the work overload, the job makes us sick. (I15)

The nursing team faces challenges in promoting the user's protagonism, in the effective construction of a unique therapeutic project (PTS), in the distribution of daily tasks with other health professionals, and the protagonizing care:

The mental health nurse does not have only physical distress as colleagues have in the clinics [...] has a very big mental distress as we stand as crisis mediator between the unbearable and the subject, and then again we are the wall. (115)

According to the nursing staff, the reality of wreckage triggers a work process that does not help in the production of mental health care linked to the Brazilian Psychiatric Reform:

I had all my nursing training guiding the clinical issues. It is $95 \%$ of the theme, the clinical issues. Little is said about the psychological issue, very little. (12)

The health formation is quite "hospitalocentric" yet; you leave college knowing how to work in a hospital, knowing how to take care of a chronic renal conjunctive infection, but you don't leave knowing how to listen to the subject. (114)

The researchers observed, according to data analyzed in the field journal, a strong concern of CAPS III professionals during the final farewell event of the research team, related mainly to the situation of SUS and CAPS in the city of Rio, due to the precarious financing and planning of services, as well as professional devaluing.

Therefore, in the face of cultural narratives, such as those exposed here, social constructionism points to the need to understand them to discover a collective sense of their history and fate ${ }^{(5)}$.

\section{DISCUSSION}

In its different forms, violence represents a new profile in the world of health problems, and health care professionals are prone to suffering from various forms of violence in their work environment $^{(12)}$.

According to social constructionism, social conflicts exist because they are treated individually, without the necessary dialogue to share in relationships what is true, real, and good. Such individualism in the resolution of disorders will lead to the non-sharing of ideas and dialogues, tending to increase disorders ${ }^{(5)}$. Conflicts are part of the world, and, although some are terrifying, only through dialogue will a solution be possible, and that is what in constructionism is called "conflict reduction practices." (5).

For social constructionism, when understood that the problem is not in us, but the system, part of the doubt about ourselves disappears, opening possibilities for new alternatives for actions and conflict resolutions ${ }^{(5)}$. 
The evidence of violence as a phenomenon that prevents CAPS from advancing in the territory is a public health alert for society. When this CAPS does not advance, it closes on itself, institutionalizing and breaking with the psychosocial paradigm and psychiatric reform logic. Even though violence provides a distance for CAPS III users because there is a clinic present in the territory, it is urgent to cope with such conflict through an intersectoral dialogue with more active public policies in vulnerable territories.

In short, territorial violence reduces the possibility for the user to fully exercise his protagonism and creates obstacles for the nursing team to fulfill the protagonist's care. According to the nursing staff's perception, this fear silences the user's care in the territory that professionals do not access either. It is worth reiterating that CAPS is also a place of protection and reception to the user, marked by vulnerabilities linked to territorial violence in an urban context such as that of Rio de Janeiro. Therefore, territorial violence affects one of the pillars of psychosocial rehabilitation in terms of living, harming the user's ability to be in the spaces of CAPS and the territory. This difficulty of access creates barriers to nursing care based on psychosocial aid and social inclusion because it will have to give up community spaces. Furthermore, violence makes it difficult and sometimes impossible to exchange views in the territory and form bonds and social support.

The issue of low education is another barrier to CAPS user's protagonism and a reality identified by the nursing staff as a permanent challenge since, on the street, at work, and in society, these subjects will suffer marginalization for not having access to literacy. This phenomenon mainly affects psychosocial rehabilitation regarding inclusion through work since the labor market does not absorb the user due to limitations imposed by illiteracy.

Social constructionism favors the recognition of cultural tradition, which will be shared. It is a context of the time lived because the facts narrated may be similar, but their description depends on tradition and writing ${ }^{(5)}$. In this sense, the CAPS III nursing team strives to build forms of instruction and communication (e.g., a seminar called "Café com Letras" [Coffee with Letters]) to ease the barriers imposed by the high rate of illiteracy of users.

The nursing staff is active in creating mechanisms for the recognition of cultural values. Thus, nursing uses a language close to the user and creative actions to establish a positive connection. Despite this, they recognize that illiteracy is a phenomenon that needs to be addressed beyond CAPS III, a problem that involves an intersectoral resolution, that is, beyond health services.

Regarding the challenge related to family non-adherence, it is necessary to say that the classic view about the family and its responsibility for its members'illness has not been offering the possibilities for a care alliance. Reinforcing this difficulty, health professionals tend to establish alliances with users, assuming a certain degree of criticism of family members, making it difficult to intervene neutrally in the way the family works. It requires co-responsibility between the family and the user for the best mental health care in an ideal context ${ }^{(10)}$.

The user's familiar relationship with CAPS is a primordial device in the production of protagonist care, whose therapeutic advance requires adherence to treatment and follow-up. Therefore, family members' adherence difficulties and denial of the disease must be addressed as part of treatment and transformed into constructive care dialogues.
The nursing staff builds mechanisms to call for this family participation in the CAPS III user's treatment, understanding that there is also the need for this family member to be assisted and guided. That is a work of cultural deconstruction of the figure of the excluded madman and begins in the family's first cell to understand the complexity of mental illness, which should not result in social exclusion.

Another challenge identified in the study refers to the difficulties in handling the crisis, which causes discomfort in the nursing staff. This uneasiness at the moment of the intervention will vary according to the degree of bond established. In this sense, a study has already identified management patterns by nurses to people in psychotic outbreaks, in which a large part of the nursing staff shows unpreparedness ${ }^{(13)}$.

Professionals perceive the restraint of the CAPS user crisis by the nursing staff as a paradoxical limit between tension and relief. It also presents itself as a moral dilemma because the staff feels forced, lonely, and with the permanent obligation to decide between the staff's tension limit at risk of physical aggression and the relief of restraining a patient who will be more protected.

The physical restraint represents an aggressive and critical professional past and subject to criticism for nursing and exposes a contradiction in the face of new care practices. However, such practice continues to be demanded by many professionals from several areas, whose execution remains a nursing action, which will bear the emotional costs of this physical intervention.

Furthermore, an issue is the clear signs that CAPS professionals are dissatisfied with work management due to the lack of investments and infrastructure and inadequate organization of the work process $^{(14-15)}$. The low contribution of resources to public health services breaks with social inclusion and equity since excludes many of the population from assistance in the Unified Health System.

Finally, the nursing staff's inadequate technical training highlights an aggravating factor for the quality of mental health care provided and the protagonism production. Without continuous and permanent education, the old asylum practices will be reproduced, uncritically, at CAPS. Therefore, it is necessary to strengthen the psychosocial care model, which implies the revision of the curricula of training schools and the creation of new scenarios for professional training ${ }^{(13)}$.

\section{Study Limitations}

The study pointed out limitations regarding the data collection scenario since it was not conducted in other mental health care contexts or other CAPS types due to the confrontation between military and drug traffickers during the research period.

\section{Contributions to the fields of Nursing, Health or Public Policy}

The research brings contributions to the challenges for a nursing clinic in the social field, psychosocial rehabilitation, and protagonist care construction. It also pointed out: the existing difficulties for this type of care in CAPS, which are organizers of mental health care in the Psychosocial Care Network, and the need for investments in public policies. Still, the study highlights the nursing staff's work in a permanent negotiation with the territory and the individual's territorialities. 


\section{FINAL CONSIDERATIONS}

Nursing challenges for protagonist care in the Psychosocial Care Center are territorial violence, the high rate of users who have low literacy, and the difficulties of family members in understanding and integrating themselves into a form of care that requires the highest possible degree of autonomy by the subject. The phenomenon of violence in the territory presents the risk of services "closing themselves off," involving neither the family nor the territory.

The low level of users' education is a problem whose solution or confrontation has not yet been developed in the Centers and has been generating, in these individuals, social exclusion and difficulty of personal organization. In its diverse and plural dimension, the family has a vital role in the processes of social exchange and inclusion of the service user. Its attachment to the traditional diagnostic treatment and drug intervention, which has no potential for social inclusion because they need to develop bonds, has been an issue to be discussed carefully. It seems to be related to the cultural history of madness and the proposal of social separation as a simplistic answer to the difficulties that culture presents in including madness in everyday life.
The nursing staff feels uncomfortable taking care of the user during the crisis, with the possibility of physical restraint. This discomfort combines difficulties related to the challenging clinical management of the situation, a frequent obligation to contain an individual with whom was established a bond, and some professional loneliness in carrying out this intervention.

The wreckage of the Psychosocial Care Center and dismantling of the Unified Health System bring many difficulties for advancing the Brazilian Psychiatric Reform. Moreover, nursing care challenges indicate staff exhaustion, but that does not prevent nursing from betting on the possibility of the protagonist's care.

Given all the nursing staff's challenges, the need for more significant investments in social policies for the psychosocial rehabilitation process in the Psychosocial Care Center territory is clear. Even in the face of this scenario, the nursing staff that brings with it the valorization of psychosocial rehabilitation is like a clinical mechanism to promote user autonomy and freedom and break with processes of exclusion and marginalization.

\section{ACKNOWLEDGMENT}

We thank the study participants.

\section{REFERENCES}

1. Amarante P, Nunes MO. Psychiatric reform in the SUS and the struggle for a society without asylums. Ciênc Saúde Colet. 2018;23(suppl 6):2067-74. https://doi.org/10.1590/1413-81232018236.07082018

2. Oliveira RMP, Alves M, Porto IS, Cavalcanti PCS. The psychiatrical nursing clinic and its new care technologies. Rev Pesqui: Cuid Fundam. 2016;8(supp 1):3922-34. https://doi.org/10.9789/2175-5361.2016.v8i1.3922-3934

3. Dutra VFD, Bossato HB, Oliveira RMP. Mediating autonomy: an essential care practice in mental health. Esc Anna Nery. 2017;21(3):e20160284. https://doi.org/10.1590/2177-9465-EAN-2016-0284

4. Maftum MA; Pagliace AGS; Borba LO; et al. Changes in professional practice in the mental health area against Brazilian psychiatric reform in the vision of the nursing team. Rev Pesqui: Cuid Fundam. 2017;9(suppl 2):309-14. https://doi.org/10.9789/2175-5361.2017.v9i2.309-314

5. Gergen KJ, Gergen M. Construcionismo Social: um convite ao diálogo. Rio de Janeiro: Instituto Noos; 2010. 119p.

6. O'Brien BC, Harris IB, Beckman TJ, Reed DA, Cook DA. Standards for reporting qualitative research: a synthesis of recomendations. Acad Med. 2014;89(9):1245-51. https://doi.org/10.1097/ACM.0000000000000388

7. Qrs. Nvivo. Versão Nvivo Pro 12 for Windows 2018 [Software][Internet]. 2018 [cited 2020 Jan 25] Available from: http://www.qsrinternational. com/nvivo-portuguese

8. Sawaya AL, Albuquerque MP, Domene SMA. Violência em favelas e saúde. Estud Avan. 2018;32(93):243-50. https://doi.org/10.5935/0103-4014.20180041

9. Bordignon M, Monteiro MI. Violence in the workplace in Nursing: consequences overview. Rev Bras Enferm. 2016;69(5):939-42. https://doi. org/10.1590/0034-7167-2015-0133

10. Belloti M, Fraga HL, Belloti L. Family and psychosocial attention: care for the person with abusive use of alcohol and other drugs. Cad Bras Ter Ocup. 2017;25(3):617-25. https://doi.org/10.4322/2526-8910.ctoAR0988

11. Krachenski NB, Holanda AF. Crisis management in psychosocial care centers: a systematic literature review. Rev Psicol Fae [Internet]. 2019 [cited 2020 Jan 25];8(1):23-42. Available from: https://revistapsicofae.fae.edu/psico/article/view/233/143

12. Fernandes H, Sala DCP, Horta ALM. Violence in health care settings: rethinking actions. Rev Bras Enferm . 2018;71(5):2599-601. https://doi. org/10.1590/0034-7167-2017-0882

13. Oliveira A, Garcia APRF, Toledo VP. Patterns of knowledge used by nurses in caring for the patient in the first psychotic outbreak. Esc Anna Nery. 2017;21(3):e20170001. https://doi.org/10.1590/2177-9465-EAN-2017-0001

14. Paim JS. Thirty years of the Unified Health System (SUS). Ciênc Saúde Coletiva. 2018;23(6):1723-28. https://doi. org/10.1590/1413-81232018236.09172018

15. Bittencourt MN, Oliveira DCP, Souza RPO, Pena JLC, Pantoja PVN, Pereira MO. Ombudsman's experience in Psychosocial Care Centers for alcohol/drugs. Rev Bras Enferm. 2018;71(Suppl 5):2287-94. https://doi.org/10.1590/0034-7167-2017-0924 